Using the Harvard HRM model to conceptualise the impact of changes to supervision upon HRM outcomes for different types of Australian public sector employees

Yvonne Brunetto BA, DipED, PhD

Associate Professor in HRM

School of Commerce and Management, Southern Cross University

P.O Box 42, Tweed Heads,

NSW. 2485 AUSTRALIA

ph: +61 255069373

Fax: +61255069370

Mobile: 0408192098

Email: yvonne.brunetto@scu.edu.au

Rod Farr-Wharton B.Sc, M.Sc. PhD

Faculty of Business,

University of the Sunshine Coast,

Maroochydore, Queensland. 4558, AUSTRALIA

Ph: +61 754301217

Email: rfarr@usc.edu.au

Kate Shacklock B.Ec, PhD

Department of Management, Griffith University - Gold Coast campus

Southport 4215, Queensland, AUSTRALIA

ph: +617 55528543

Fax: +61 755529206

Email: k.shacklock@griffith.edu.au

\title{
Correspondence:
}

yvonne.brunetto@scu.edu.au 


\begin{abstract}
Within the Australian context of a shortage of skilled professionals, this paper uses the Harvard model of HRM to conceptualise how changes in stakeholder interests coupled with changes to situational factors affect public sector HRM policy choices that in turn affect HRM outcomes for different types of public sector employees. The findings obtained using path analysis suggest that the proposed model explained almost $50 \%$ for nurses and less than $14 \%$ for police officers. In the case of nurses, the strong significant relationship between HRM inputs and outputs may provide a further plausible explanation for one of the long term consequences of NPM - namely, the inability to retain skilled employees (especially those in the health sector) across numerous OECD countries. The implication of these findings is that the present public sector HRM policy choice should be re-examined because of its impact upon HRM outcomes. Moreover, public sector employees should not be regarded as one uniform group that responds alike to the same policy. Whilst the merits of pursuing a strong auditing focus may have benefited organisations financially, the benefits can only remain if public sector employees, including professionals, are prepared to work under those conditions. The inability to retain nurses in numerous countries, coupled with past studies that have identified (poor) management as a contributing factor, suggests that past HRM policy choices may have to be replaced by new HRM policy choices that focus on employees' perceptions of well-being. However, more studies using different types of professionals are required to confirm the generalisability of these findings.
\end{abstract}

Keywords: Affective commitment, Employee's perception of well-being, Harvard model of HRM, HRM, Professional employees, Supervision practices. 


\section{Using the Harvard HRM model to conceptualise the impact of changes to supervision upon HRM outcomes for different types of Australian public sector employees}

\section{Introduction}

An important issue for Australia is the retention of skilled employees because it is a key factor affecting organisational effectiveness (Gollan, 2005; Productivity Commission, 2005). In the case of health professionals, past research suggests that the main factors affecting supply include the aging population, inadequate numbers attracted to the professions and high turnover (Buchan and Calman, 2004; Buerhaus, Staiger and Auerbach, 2006; Schofield and Beard, 2005). To date, the focus of public sector efficiency research has been on lowering costs by linking overall performance to better patient outcomes (Shortell, et al, 1994). However, there has been limited research linking retention of professionals to overall performance and patient/customer outcomes, even though lower turnover would reduce the cost of recruitment and training and improve the service to the public.

HRM practices have changed in public sector organisations over the past two decades because of the implementation of New Public Management (NPM). NPM refers to the adoption of private sector management tools by public sector organisations so as to make organisational processes and practices more efficient and in turn, facilitate a change from an input to an output focused system (Boyne, Jenkins and Poole 1999). Some public sector researchers argue that NPM has now been replaced with new public sector management approaches that focus more on governance by policy communities and networks - in turn addressing some of the problems identified with its implementation (Dunleavy, Margetts, Bastow and Tinkler 2006). Others argue that irrespective of the next stage in public sector management, a key legacy of NPM is greater standardization of work achieved by increased accountability of public sector employees (Broadbent and Laughlin, 2002). Since much of the responsibility for implementing increased accountability in practice rests with supervisors, it is important to 
examine if the implementation of NPM has changed the supervisor-subordinate relationship for different types of public sector employees, especially since supervisors are now expected to use their increased power to monitor, measure and assess performance of human resources to a far greater extent (Brunetto \& Farr-Wharton 2006, 2007; Ackroyd, Kirkpatrick and Walker 2007; Adcroft and Willis 2005). This is particularly important because some researchers have identified an effective supervisor-subordinate relationship as the factor most likely to improve commitment and retention (Cohen, 2006; Tauton, Boyle \& Woods, 1997), yet there is limited research on these matters within the public sector context. Hence, whilst there is consensus that the impact of NPM on management practices was not a "single phenomena with a uniform interpretation” (Boyne 2003, p. 224); and Gould-Williams (2004) contends that the impact of NPM on HRM was only ever somewhat "selective" and therefore limited in its impact, (, Boyne et al. 1999), it does appear that one HR function that has changed is the supervisory function. However, it is unclear how the change in the supervisorsubordinate relationship has impacted on different types of public sector employees.

This paper uses the Harvard HRM model to examine how changes in stakeholder interests (such as the change in management philosophy that facilitated the implementation of NPM) coupled with changes in situational factors (such as an ageing population in addition to a shortage of trained employees) led to HRM policy choices in the public sector (particularly in relation to supervision practices) that in turn affected HRM outcomes (by affecting employees’ levels of affective commitment) (Beer, Spector, Lawrence, Mills, and Walton 1985). In particular, the paper examines how HRM outcomes may be different for diverse types of public sector employees. Whilst there is growing literature connecting HRM practices and organisational effectiveness (Gollan 2005; Guest and Conway 1997; Ostroff and Bowen 2000; Ostroff, Kinicki and Clark 2002; Simons and Roberson 2003), the focus has 
been on perceiving public sector employees as a single group of employees - and this issue has important implications for the sustainability of the public sector.

The Harvard model is an ideal model to use within the context of the public sector, because it is useful in tracking how a change in HRM policy choices (resulting in public sector employees facing increased workloads, reduced relative pay, poorer working conditions, inflexible scheduling, increased intensity of work, loss of work autonomy and increased accountability and supervision, especially in relation to increased record keeping and data collection (Ackroyd, Kirkpatrick and Walker 2007; Adcroft and Willis 2005; Brunetto and Farr-Wharton 2005; 2006b; 2007; Buchanan and Considine 2002; Gould-Williams 2004; Newman, Maylor and Chansarkar 2002) affects HRM outcomes. Numerous studies have identified HRM outcomes as a reduced level of satisfaction of public sector employees about many HRM policy choices (Ackroyd, et al 2007; Brunetto and Farr-Wharton 2005; 2006b; 2007; Buchanan and Considine 2002; Gould-Williams 2004; Newman, et al. 2002). However, there is less evidence about the differences in HRM outcomes for different types of public sector employees from the same HRM policy choice.

The purpose of the research is to challenge whether the benefits associated with the reduction in per capita costs (resulting from the past implementation of NPM) may be negated and replaced in the longer term by an even greater cost to redress new problems associated with a reduced perception of well-being by those public sector employees now in short supply namely some professional employees such as nurses. Certainly, Ackroyd et al (2007, p. 23) argue that there has been little attempt by government to 'evaluate whether management reforms ... actually work' for all stakeholders concerned. Surely a reform could not be considered successful, if the same reform contributed to a shortage of employees required to deliver the public good or service. It is proving a costly consequence for public sector management to replace professionals. For example in the USA, it is estimated to cost 150 
percent of a nurse's annual compensation to replace a nurse that leaves (Contino 2002) and this is likely to be similar across OECD countries. The sustainability of public sector organisations such as hospitals continuing to deliver labour intensive services to the public rests with ensuring that they have a sufficient supply of trained employees. If different types of public sector employees do experience different reactions to the way the same HRM policy choice is implemented, this may provide a further plausible explanation for one of the emerging longer term consequences - an inability to retain some public sector employees and particularly professionals in the health sector across numerous OECD countries (doctors, nurses and allied health professionals) (Brunetto and Farr-Wharton 2006, 2007; Buchan and Claman 2004; Buerhaus, Staiger and Auerback 2000; Buchanan and Considine 2002).

This paper is one attempt to identify and measure the impact of one HRM policy choice (supervision practices) on the HRM outcomes (such as employees' perceptions of well-being and affective commitment -commitment to the organisation) for two different types of public sector employees (see Figure 1). This is an important issue because past research suggests that the implementation of organisational reforms does impact upon public sector employee outcomes, including their perception of well-being in the workplace and commitment (Mikkelson, Osgard and Lovrich 2000). Moreover, past research has identified affective commitment as a predictor of labour turnover and job performance (Pitt, Foreman and Bromfield 1995), and affective commitment is considered a major determinant of organisational effectiveness (Meyer and Herscovitch 2001).

This paper has three sections. The first part provides a targeted review of the literature from which the hypotheses emerge. The second part describes the sample and methods to test the hypotheses and address the research questions. The third part reports the results and uses the discussion section to identify pattern-matching with relevant past research and implications for hospital managers, followed by the concluding remarks. 


\section{Background}

\section{Examining the impact of changes in stakeholder interests on public sector management}

The basis of public sector reform over the past two decades rests with the growing acceptance of neoliberalism, which argued that bureaucratic government organisations were inefficient and wasteful compared with organisational processes of the private sector because they were forced to respond to competitive market forces. For example, one of the catalysts for implementing NPM by the Australian government was the emergence of "new right intellectuals ...[drawing on]... the ideas of American public choice economists" who pontificated that the public sector "suffered from gross inefficiency and waste" (Orchards 1998, p. 20-21). Whilst there has been much criticism of the theoretical framework underpinning the introduction of NPM and numerous researchers challenge the scientific basis of the NPM reforms, most researchers acknowledge the significant impact of the implementation of NPM on public sector HRM (Argyriades 2006, p. 281; McLaughlin, Osborne and Ferlie, 2002).

However, its implementation across OECD countries has not been uniform (Denhardt and Denhardt, 2007). For example, in Britain and New Zealand the focus has been on separating policy development from service provision, whereas in Australia, the focus has been on the adoption of increased managerial control to achieve government objectives (Carroll and Steane, 2002; Harris 1999). One of the main government objectives associated with the implementation of NPM in Australia, NZ and the UK was significant cost cutting (Adcroft and Willis 2005; Kirkpatrick and Lucio 1995) and this strongly influenced the type of HRM practices adopted within different workplaces (Gould-Williams 2004) and the type of performance indicators used to measure and monitor processes (Power 1997). 
One implication of the approach taken in Australia and the UK is that the role and power of public sector managers has expanded significantly to incorporate more functions (such as performance management, monitoring and evaluation) in turn, affecting how employees work. However, in each different public sector workplace, the degree to which employees have experienced reduced autonomy and/or work intensification has been dependent on the ability of supervisors for 'mediating the excesses of NPM [new public management]' (Kirkpatrick and Ackroyd, 2003; Ackroyd et al, 2007, p. 21). On the other hand, supervisors' ability to mediate between organisational and professional goals has also been constrained by the increased managerial autonomy imposed by higher level of management dictating specific objectives to be met by supervisors (Butterfield Edwards and Woodall, 2005).

Hence, whilst the implementation of NPM focused on changing seven major organisational practices, the changes that most affected the supervising role were: a new organisational focus on achieving outcomes, giving supervisors of professionals in particular more power and the introduction of measurement tools that could be used to monitor and assess performance in relation to appropriate standards of services (Broadbent and Laughlin; 2002; Ackroyd et al, 2007). Whilst changes in HRM practices are likely to have a significant impact upon employees in all circumstances, the contextual situational factors may have compounded the impact for some types of public sector employees more than others. The following section examines the present situational factors in which such changes in HRM have been implemented.

\section{Examining the impact of changes in situational factors on public sector management}

Numerous developed countries are currently experiencing ageing workforces combined with a growing shortage of skilled labour (OECD 2003). There are a number of reasons for the ageing populations, including the post World War II baby boom, followed by lower birth rates 
in subsequent generations. Combined with healthier lifestyles, advances in medical science and the consequent increase in longevity, there are now more older people than ever before and this trend will continue for several decades (Productivity Commission 2005). Combined with the shortage of younger workers and the typical early retirement of the baby boomers, researchers and others are now predicting a labour shortage in the near future (Australian Bureau of Statistics 2005; Productivity Commission 2005; Shah and Burke 2003).

This is not a new issue. According to the Australian Human Resources Institute (AHRI 2003), recruitment and retention of skilled employees was the number one business success factor, and from both CEOs' and HRM Practitioners' perspectives. Further, this report identified that the dominant three business challenges in today' organisations are; (i) labour supply, (ii) recruitment, retention and talent management and (iii) skills shortages. Australia's changing demographics and ageing population are contributing to an overall shortage of people, and combined with incentives for early retirement, are reducing labour supply (Shah and Burke 2003).

This is an important issue for public sector HRM management because numerous OECD countries such as Australia, Northern America and Europe face shortages of some public sector employees - especially medical professionals - and high turnover resulting from poor management practices has been identified as a key factor (see Buchan and Claman, 2004, Buchanan and Considine 2002, Contino 2002, Degeling, Sage, Kennedy, Perkins and Zhang 1999). Hence, if supervision practices are perceived negatively by professional employees already in short supply because of demographic factors, and this in turn contributes to public sector organisations being unable to service the public, then there are indeed organisational ramifications of continuing with such practices for those types of public sector employees. The following reviews the influence that the chosen HRM policies have upon supervisors in particular, and nurses by way of an example. 


\section{Examining the impact of changes in the HRM policy choice}

This paper focuses only on the emerging general trends in supervision across organisations and countries. In terms of supervisory practices, public sector managers indicate that the biggest issue has been in their change of focus. They are now expected to mediate between organisational goals and professional/culturally-embedded goals, often forcing supervisors to focus on their auditing role rather than their supporting role, and this has been particularly difficult for those supervising professionals (Kirkpatrick and Ackroyd 2003; Power 1997; Whittington, McNulty, and Whipp 1994). Accordingly, supervisors have now been given increased responsibility to monitor, measure and assess performance of human resources to a far greater extent (Brunetto and Farr-Wharton 2005; Ferlie, Ashburner, Fitzgerald and Pettigrew 1996; Wanless 2000).

For example, nurse managers in the UK have been expected to "create empowering social environments" within the context of "tight budgetary controls and performance measures and targets” that override all other goals (Bolton 2003, p. 126). Similarly, Ackroyd et al (2007) argue that the supervisor-subordinate relationship suffered because nurse unit managers (NUMs) were placed in a position of having to ask nurses to undertake more auditing-type activities, such as "clinical audit, focused on directing professional decisions on resource utilization”. As a result, some argue that this has negatively impacted on their supervisory relationships. It is therefore unclear whether such changes to supervisory practices have affected different types of public sector employees' levels of satisfaction with their supervision and whether this has, in turn, affected their HRM outputs. One typical measure of the quality of the supervisor-subordinate relationship is captured in leader member exchange (LMX), which is examined next. 
The role of leader member exchange

LMX theory argues that supervisors do not treat all employees the same and therefore the quality of LMX varies. When there is a high level of support, trust and respect between the two, a high quality LMX results (Gerstner and Day 1997; Mueller and Lee 2002). Employees who experience these are called the in-group. In contrast, the out-group suffers poor quality LMX relationships characterised by a low level of support, trust and respect between the two. Moreover, supervisors usually like their in-group, irrespective of their performance (Graen and Uhl-Bien 1995). As a result, the in-group receives better access to information, assistance and involvement in decision-making, which in turn, makes it easier for them to undertake tasks and solve work-related problems (Haskins 1996). Subsequently, supervisors can count on these employees to provide them with extra support for their decisions (Graen and UhlBien 1995; Mueller and Lee 2002; Wayne, Shore and Linden 1997).

Previous research has already identified that LMX affects employees' levels of job satisfaction (Epitropaki and Martin 1999; Janssen and van Yperen 2004), job commitment (Epitropaki and Martin 1999), Perceived Organisational Support (POS) (Wayne et al. 1997) and the quality of communication processes generally (Brunetto and Farr-Wharton, 2006; Mueller and Lee 2002). A high quality LMX is associated with increased information flow and empowering relationships as a result of supervisors allocating increased levels of organisational resources (time) towards each subordinate (Mueller and Lee 2002; Sparrowe and Linden 1997). On the one hand, when high quality LMX relationships are present, supervisors are likely to provide employees with meaningful feedback and delegate decisionmaking and power (Spreitzer 1995; 1996; Yukl and Fu 1999). On the other hand, if the supervision function is compromised, then it may also negatively affect different types of public sector employees’ perceptions of well-being and their levels of affective commitment. 


\section{Examining some of the HRM outcomes}

Employees’ perceptions of well-being

The study of employees' perceptions of well-being is relatively new. As a result, a diverse range of terms has been used to conceptualize it, such as 'psychological well-being' (Cooper and Cartwright 1994; Daniels and Guppy 1994; 1997), 'affective well-being’ (Warr 1987; 1990), ‘mental health’ (Anderson and Grunert 1997; Price and Hooijberg 1992; Wright and Bonett 1992;), 'general health’ (Burke and Greenglass 2000; Petterson and Arnetz 1997; Tyler, Carroll and Cunningham 1991), 'organisational well-being' (Thomsen et al. 1999) and ‘employee well-being’ (Lapierre and Allen 2006; Thompson and Prottas 2006).

Additionally, there is a lack of consistency in terms of frameworks for conceptualising 'wellbeing in the workplace'. Warr (1987; 1990), for example, uses the term 'affective well-being' in his framework as a component of mental health (the other components of health are 'competence', 'autonomy', 'aspiration' and 'integrated functioning'). On the other hand, Danna and Griffin (1999) perceive 'health' as a sub-component of 'well-being' because the latter is considered to be broader and more encompassing than the former. Their framework comprises the combination of mental, psychological, physical and physiological indicators, and general physical health. As such, they argued that employees’ perceptions of well-being was a function of four variables - their perception of: competence (how well they can perform workplace tasks), autonomy (belief about their ability to determine when and how tasks will be undertaken), aspiration (beliefs about the future opportunities) and integrated functioning (how well employees combine different tasks) (Danna and Griffin 1999, p. 362).

In summary, three different conceptualisations of well-being are evident: (i) psychological well-being, which examines employees' levels of satisfaction with processes and practices associated with the workplace, (ii) physical well-being, which examines well-being in terms 
of employees' health outcomes (from stress and accidents for example) and (iii) social wellbeing, which is affected by the quantity and quality of workplace social networks as well as employees' perceptions of fairness and equity (Grant et al. 2007). In terms of the psychological approach, two components have been identified. The hedonic part focuses on employees' perceptions of pleasure invoking either negative or positive thoughts or feelings. It is usually measured by employees' levels of job satisfaction. The eudaimonic part refers to employees' perceptions of whether they have reached their potential and is therefore measured by employees’ feelings of fulfilment in reaching their goals (Grant et al. 2007).

Employees' perceptions of well-being are increasingly perceived as important employee measures of HRM outcomes (Judge and Watanabe 1993, Gerstner and Day 1997). However, as a result of multiple ways of conceptualising well-being, research about well-being has used a range of measures. For example, Burke and Greenglass (2000) measured well-being based on psychosomatic symptoms (for example, headaches) or lack of well-being, while the measure adopted by Parasuraman, Greenhaus and Granrose (1992) was based on job satisfaction and life stress. However to date, no specific measure has been developed to test a broader conceptualisation that captures the two components identified in using the psychological approach - both the hedonic and eudaimonic component of well-being. For this reason, this paper develops and tests a new instrument of well-being to examine the following hypothesis:

Hypothesis 1: There is a significant positive relationship between LMX and employees' subsequent perceptions of well-being.

\section{Affective commitment}

Affective commitment is defined as the emotional attachment to, and identification with, an organisation (Allen and Meyer, 1990) and those with high levels of affective commitment are 
likely to be loyal and attached to the organisation, in turn, reducing their likelihood of leaving (Meyer and Allen 1997; Pitt, et al. 1995). Previous research suggests that communication practices and the relationship with the supervisor do affect the commitment of a range of public sector employees (Brunetto and Farr-Wharton 2004b, 2006a, b, 2007). For this reason, it is expected that there will be a positive significant relationship between LMX and affective commitment. To examine this premise, the following hypothesis is proposed:

Hypothesis 2: There is a significant positive relationship between employees' satisfaction with LMX and their level of affective commitment

Moreover, previous research suggests that organisational policies (about pay and appraisal methods), management practices and poor levels of workplace relationships negatively affect the commitment of nurses (Buchanan and Considine 2002; Brunetto and Farr-Wharton 2004b, 2006a, 2007; Neuman, et al, 2002). Whilst there is minimal previous research linking well-being and affective commitment, there is research that links well-being with job satisfaction (and job satisfaction is significantly related to affective commitment) (Judge and Watanabe 1993) and LMX with well-being (Gerstner and Day 1997). Hence, it is expected that there will be a significant positive relationship between public sector employees' perceptions of well-being and their levels of affective commitment. To examine this premise, the following hypothesis is proposed:

Hypothesis 3: There is a significant positive relationship between employees' perceptions of well-being and their levels of affective commitment.

\section{Examining some of the long term consequences for different types of employees}

Professional employees (as per the Anglo-American model in Evetts and Buchner-Jeziorska 1997) are those who are eligible to belong to professional associations that work with universities and governments to control the number of employees gaining the skills and accreditation for entry into the profession. Nursing is an example of a relatively new 
profession with numerous countries now encouraging more university-trained graduates as the preferred route of entry to the profession. Professional employees have historically been largely protected from rapid changes in the workplace (Dingwall and Lewis 1983), yet previous paragraphs have detailed mounting evidence that all professionals, including nurses, have experienced increased paperwork as well as an increased workload and pace of work. In addition, nurses have had to contend with increased acuity of patients under their care (Buchanan and Considine 2002; Hegney, Plank, Buikstra, Parker and Eley 2005; Neuman, Maylor and Chansarkar 2002). Whilst professional public sector employees now face increased workload and accountability, there is evidence that their professional status has provided their supervisors with the power to "mediate top-down demands" far more than for other public sector employees (Ackroyd, Kirkpatrick and Walker 2007, p. 22). This means that professional employees should have a higher rate of satisfaction with the quality of LMX compared with other public sector employees (Brunetto and Farr-Wharton 2005, 2007) and therefore, they should also experience higher levels of well-being and affective commitment. To examine this issue, nurses are used as examples of professional employees and police officers are used as examples of another types of public sector employee. Nurses and police officers are compared in this study because in contrast to nurses, who are expected to have professional qualification), police officers do not require a professional qualification in many OECD countries (Evetts and Buchner-Jeziorska 1997). In some countries, nurses do not require formal university qualification, however, even in those countries there is an increasing trend towards nurses gaining professional qualifications (See Robinson, Murrells and Clinton, 2006 in the case of the UK). This means that nurses are expensive for a government to train and therefore it is imperative that the managers' retain them. The hypothesis is: 
Hypothesis 4: Nurses experience higher levels of satisfaction with LMX compared with police officers and therefore will also have higher perceptions of well-being and affective commitment.

The above hypotheses are used to guide data collection, which was undertaken as explained in the next section.

\section{Methods}

This study operationalised the Harvard model of HRM using surrogate instrument to measure the impact of one HRM policy choice (supervision practices) on the HRM outcomes (such as employees' perceptions of well-being and affective commitment -commitment to the organisation) for two different types of public sector employees. It uses Leader-member exchange (LMX) as a measure of employees' level of satisfaction with their supervisorsubordinate relationship. It uses a new construct of wellbeing and it uses Allen and Meyer's (1990) commitment instrument (which measures commitment to the organisation) to measure HRM outcomes.

A survey-based, self-report strategy (Ghauri and Gronhaug 2002) was used to obtain data from public sector nurses and police officers to examine the impact of the supervisorsubordinate relationship (which has changed because of changes in stakeholders' interests, in turn affecting HRM policy choices) on HRM outcomes. Path analysis is used to test the impact of supervision practices on firstly, employees' perceptions of well-being and in turn, affective commitment. In particular, path analysis using an ordinary least square (OLS) approach is used to test the hypotheses. The advantage of path analysis is that it permits more than one equation to predict the dependent variable (i.e. affective commitment) and therefore it includes the indirect impact of well-being into the bigger equation. OLS is an explanation of variance and the overall $\mathrm{R}^{2}$ measure identifies the 'goodness of fit' overall for the proposed 
model (Ahn 2002). Another advantage of using path analysis with an OLS approach is that it estimates parameters within an independent system, which could avoid the problem of multicollinearity (Grapentine 2000). For this reason, OLS is used for analysis of the data.

\section{Sample}

The practices of public sector nurses and police officers have changed in a number of countries such as Australia, New Zealand, Canada and the UK. For convenience, the study was focused in one Australian state. The HRM practices used in public sector hospitals and police stations are somewhat similar, especially since the introduction of standardized processes particularly in relation to monitoring, measuring and appraising the performance of human resources (Adcroft and Willis 2005; Wanless 2000). In Australia, the public sector in general is publicly accountable, required to have transparent decision-making, and HRM functions in different organisations are governed by the same legislative bases, and consequently have well-developed policies and practices about most HRM activities. Both hospitals and police HRM systems therefore are similar in terms of compliance and regulation, including equal employment opportunities, health and safety compliance, compulsory superannuation and the like. As such, any one public sector hospital or police station is arguably representative of what happens in most public hospitals and police stations, though local demographic and socio-economic factors will obviously impact upon the types of activities dominating each specific hospital or police station. According to Stanton, Bartram and Harbridge (2004), little attention has been given to HRM in healthcare, yet the industry is highly unionized, which influences HRM and especially in public hospitals. Two hospitals were approached and both agreed to be involved in the study. One was located in a city and the other in a regional area of south-eastern Queensland - so as to capture nurses from a range of Australian public sector hospital settings. In the case of police officers, a 
region of south-eastern Queensland comprising two districts each containing approximately ten police stations was chosen. Five out of the ten police stations in each district were randomly chosen for data collection.

In all locations, questionnaires were handed out to those nurses and police officers on day shift during a weekday. Because many public sector nurses and police officers engage in shift work, the nurses and police officers captured on day shift should experience a similar work context compared with any other nurses and police officers on day shift. Questionnaires were distributed to nurses in the surgical wards of the two hospitals during a weekday. In total, 180 surveys were distributed in the city hospital and 128 completed surveys were collected and 55 surveys were distributed in the regional hospital and 36 completed surveys were collected $(\mathrm{N}=164)$. This sample captured approximately a tenth of the nurses within the two hospitals. The response rate was approximately 69.8\% percent of those surveyed. In the case of police officers, 300 surveys were distributed and 178 completed surveys were collected, a response rate of 59.33\%. The police sample captured over a fifth of the population of noncommissioned police officers (constables, senior constables and sergeants) in the region. A total of 342 surveys formed the sample. The demographics of the nurse population included twenty males and one hundred and forty-four females. The police sample comprised fortyeight females and one hundred and thirty males. See Table 1 for further details.

\section{(Insert Table 1 here)}

\section{Measures}

(a) Leader-member exchange (LMX)

a) The leader-member exchange (LMX) validated test-bank survey traditionally measures the satisfaction of employees with the quality of the relationship with their supervisorsubordinate relaitonship (Mueller \& Lee, 2002). In this study a seven item uni- 
dimensional scale (LMX-7), developed by Graen and Uhl-Bien (1995), was used. An example of a question includes "I am certain to what extent my LM will go to back me up in my decision-making."

(b) Public sector employees’ perceptions of well-being. Many studies use Warr's (1990) instrument for measuring psychological wellbeing. However, van der Doef and Maes (1999) criticised previous attempts to develop and test measures that focused too much on job characteristics and too little on the job situation itself. They argue for "more occupation-specific measurements for specific occupational groups (van der Doef and Maes 1999, p. 110). Hence, this research developed a measure of well-being specifically suited to nursing and policing.

This paper operationalised psychological well-being as a function of the hedonic part (that focuses on employees' perceptions of pleasure invoking either negative or positive thoughts or feelings) in addition to the eudaimonic part (that focuses on employees' perceptions of fulfillment in achieving their goals) (Grant, et al. 2007). An example of a survey question aimed at capturing the hedonic part of wellbeing was “Overall, I think being a nurse/police officer fulfils an important purpose in my work life”. An example of a survey question aimed at capturing the eudaimonic part of wellbeing was "Overall, I think I am reasonably satisfied with my work life”. The Cronbach alpha score for both groups was above the 0.7 threshold at .87 . (See Table 2 for a list of questions comprising the new construct of well-being')

\section{(Insert Table 2 here)}

(c) Employees' levels of affective commitment

Allen and Meyer's (1990) commitment instrument was used to measure the dependent variable - affective commitment (commitment to the organisation - using 8 items from their organisational commitment inventory. Researchers have reported Cronbach alphas ranging 
between .74 and .90 for this measure (see Allen and Meyer 1996). Nurses and police officers indicated their satisfaction with organisational factors and their perceptions about workplace stress and resultant perceptions of well-being using a 6-point Likert-type scale ranging from 1 (strongly disagree) to 6 (strongly agree).

\section{Results}

Factor analysis was undertaken and the correlation matrix identified many correlations exceeding .3, indicating the matrix was suitable for factoring. The Bartlett's test for Spericity was significant (Chi-square value=2254.117, $\mathrm{p}<.001$. df 153) and the KMO measure of sampling adequacy was .9 - well above the .6 requirement. When Principal Axis Factoring was undertaken to extract the variables, three factors had eigenvalues greater than one and $67.48 \%$ of the variance could be explained using these three factors. The factor transformation matrix suggests a relatively high correlation between factors. As stated, the advantage of using an OLS approach can avoid the problem of multicollinearity. The means, standard deviations, correlation coefficients and alpha scores for each variable are detailed in Table 3. The findings indicate that employees' perceptions of well-being are significantly related to LMX and affective commitment, but not to the control variable - age.

\section{(Insert Table 3 here)}

Hypothesis 1. In order to address the first hypothesis (Hypothesis 1: There is a significant positive relationship between LMX and employees' subsequent perceptions of well-being) a regression analysis was undertaken. The hypothesis is accepted $\left(F=251.7 \mathrm{p}<.001, \mathrm{R}^{2}=\right.$ 42.5\%). (See Table 4 for beta scores). Moreover, an examination of the relevant means suggests that the relationship is direct, although weak in effect (see Table 8).

(Insert Table 4 here) 
Hypothesis 2. In order to address the second hypothesis (Hypothesis 2: There is a significant positive relationship between employees' satisfaction with LMX and their level of affective commitment), a regression analysis was undertaken. The hypothesis is accepted for the total sample - (Analysis 1 Results $-F=199.957 p<.001, R^{2}=36.8 \%$ ), the nurses sample (Analysis 2 Results - F=72.7 $p<.001, R^{2}=31 \%$ ) and the police officer sample (Analysis 3 Results $F=11.428 p<.001, R^{2}=6.1 \%$ ) (see Table 5). Moreover, an examination of the relevant means suggests that the relationship is direct, although weak in effect however, the relationship appears inverse for police (see Table 8).

\section{(Insert Table 5 here)}

Hypothesis 3. In order to address the third hypothesis (Hypothesis 3: There is a significant positive relationship between employees' perceptions of well-being and their level of affective commitment) a regression analysis was undertaken. The hypothesis is accepted $(\mathrm{F}=230.288$ $\mathrm{p}<.001, \mathrm{R}^{2}=40.4 \%$, beta score $=.6$ ) (See Table 6 for beta scores). Moreover, an examination of the relevant means suggests that the relationship is direct, although weak in effect for nurses; however, the relationship appears inverse for police (see Table 8).

\section{(Insert Table 6 here)}

\section{(Insert Table 8 here)}

Hypothesis 4. To address the fourth hypothesis (Hypothesis 4: Nurses experience higher levels of satisfaction with LMX compared with police officers and therefore will also have higher perceptions of well-being and affective commitment) an independent t-test was undertaken. The hypothesis is somewhat supported because nurses are significantly more satisfied with both their subordinate-supervisor relationship and had a higher perception of well-being compared with police officers. However, police officers were at least somewhat committed to their organisation whereas nurses were somewhat non-committed (see Table 7).

(Insert Table 7 here) 
In addition, individual regression analyses were undertaken to demonstrate the similarities and differences across equations (see columns two and three in Tables 4 and 5). The big variation in $\mathrm{R}^{2}$ for the two samples provides further evidence of the difference in the dynamics of the relationship between LMX, well-being and affective commitment across the two public sector workplaces.

Finally, to test the model in Figure 1 using the OLS path approach involved regressing “Employees’ level of Affective Commitment” against LMX and “Employees’ Perception of Well-being”. The goodness of fit for the model overall was R2 $=46.9 \%$ (Analysis 1 Results $\mathrm{F}=149.921 \mathrm{p}<.00$ ), and $\mathrm{R} 2=47.4 \%$ for nurses (Analysis 2 Results $-\mathrm{F}=72.684 \mathrm{p}<.001$ ) and $\mathrm{R} 2$ $=13.4 \%$ for police officers (Analysis 3 Results $-\mathrm{F}=13.575 \mathrm{p}<.001$ ) (see Figure 2).

The next section of the paper will discuss the findings, highlighting areas of note and identifying critical areas from the findings that impact upon public sector management.

\section{Discussion}

This paper used the Harvard model of HRM as a framework to conceptualise and confirm the relationship between one HRM policy choice (supervision), and two HRM outcomes (affective commitment and perception of well-being) for two different types of public sector employees. As such, this study builds on the work of other researchers who have identified the link between HRM practices and organisational outcomes (See Ostroff and Bowen 2000 etc). The contribution of this paper is that the findings identified the importance of the supervision role in affecting HRM outcomes differently for different types of public sector employees (see Figure 2).

In addition, the findings from this study identify the indirect impact of supervision on wellbeing in affecting affective commitment. The goodness of fit of the model was almost $50 \%$ for nurses and less than $14 \%$ for police officers (see Figure 2), identifying a strong significant 
relationship between HRM inputs and outputs, whilst clearly revealing that the strength of the impact is not uniform across different types of public sector employees.

The findings suggest that nurses are somewhat uncommitted to their organisations and are only somewhat satisfied with supervision practices as well as their perceptions of well-being, which significantly contrasts with the policing experience. Using the Harvard model of HRM as a means of explaining the difference between the two public sector groups, four issues become evident. Firstly, is the situational context, which is a growing shortage of skilled labour because of the ageing population and early retirement (Shah and Burke 2003; OECD 2003) and this appears to have impacted particularly on nurses.

Secondly, whilst most public sector employees have experienced increased paperwork associated with increased accountability, professionals, including nurses appear to have experienced more than some other public sector employees in terms of increased paperwork, workload and pace of work as well as having to contend with the increased acuity of patients under their care. Whilst supervisors have attempted to mediate between organisational and professional goals so as to shield professionals (Bolton 2003, 2005), they have been largely forced to focus on their auditing rather than their supervising role (Ackroyd et al. 2007, Kirpatrick and Ackroyd 2003). This may explain why nurses were only somewhat satisfied with their supervision.

Thirdly, there is the different HRM outcome, suggesting that almost half the variance of nurses' affective commitment (commitment to a hospital) is predicted by both the direct and indirect influences from supervision practices as well as perceptions of well-being. This means that these independent variables appear to be very important in predicting nurses' affective commitment, whereas they were relatively unimportant, but still significant, for police officers. 
Fourthly, the long-term consequences associated with these findings differ between the two groups. One implication for nurse managers is that present supervision practices are probably contributing to the high turnover of nurses (because of the link between affective commitment and turnover rates (Pitt, Foreman and Bromfield 1995). As such, the findings may provide a plausible explanation of one of the long-term consequences: the shortage of one type of professional public sector employee - nurses - in numerous OECD countries. The way NPM was implemented may affect the supervision practices of nurses more than police officers, in turn, encouraging nurses to leave rather than to stay.

Another contribution of the paper is that it has developed and operationalised a measure of well-being which identified the significance of supervision practices on the perception of well-being for two types of public sector employees. Whilst well-being has already been identified as an important measure of HRM outcomes (Judge and Watanabe 1993), the measures previously used were general and not specific to the work content of nursing or policing. In contrast, the instrument used in this study examined well-being in terms of employees' satisfaction with an occupation-specific situation, so as to address criticisms by Van der Doef and Maes (1999) that well-being had previously been operationalised with too strong a focus on job characteristics. As such, a further contribution of this paper is that it positions the antecedents of well-being within the specific public sector work context of nursing and policing. Employees' 'perceptions of well-being' is a relatively new construct and may be useful in future studies in explaining why HRM policy choices affect different types of public sector employees’ HRM outcomes differently.

The findings suggest there was a significant difference in the perceptions of well-being of nurses compared with police officers - with police officers experiencing a lower perception of well-being as well as a lower level of satisfaction with supervision. However, perceptions of wellbeing could be explained by factors other than supervision, for example self- 
determination aspects of the job itself, working conditions, amount and quality of patient/ public contact, acuity of care for nurses and amount of violence for police officers, which are not addressed in this study. Previous research had already identified that professionals should have a better relationship with their supervisors and this was supported by the findings. However, both groups had either a low level of satisfaction with supervisors or a low level of dis-satisfaction, suggesting that supervision practices need to improve so as to improve organisational effectiveness. The present supervision practices are probably negatively affecting employees’ decisions to stay with the organisation.

The implication of these findings is that the present public sector HRM policy choice in relation to supervision has to change. Whilst the merits of pursuing a strong auditing focus may have historically benefitted organisations financially, the benefits can only remain if nurses and other professionals are prepared to work under those conditions. The shortage of nurses in numerous countries coupled with past studies that have identified (poor) management as a contributing factor suggests that past HRM policy choices associated with the implementation of NPM may have to be replaced by new HRM policy choices that focus on employees' perceptions of well-being. However, more studies using different types of professionals are required to confirm the generalisability of these findings.

Consequently, the findings challenge whether the benefits derived from a reduction in costs associated with NPM implementation have been negated and replaced in the longer term by the cost of high turnover. The longer-term consequences of the way supervision practices have been implemented may include increased costs associated with attracting, training and retaining nurses within the situational context of an ageing population. The sustainability of public sector organisations, such as hospitals, continuing to deliver labour-intensive services to the public rests with ensuring that they have a sufficient supply of skilled employees. 
The implication for governments (that determine resource levels for the provision of public goods) and public sector managers (that determine the HRM policy choices) is that there may be negative organisational consequences associated with using HRM policy choices that compromise public sector employees' perceptions of well-being - particularly if those employees are professional and therefore are expensive to train and replace (Contino 2002). If the HRM experience of nurses is negatively affecting their intention to stay in nursing because it impacts on their perception of well-being, then governments and public sector managers must factor in the costs of replacing increasing numbers of nurses. Worse, these implications are within the context of a general skills shortage in most developed countries. In other words, a different HRM approach may be needed; one that focuses on valuing skilled employees enough to change basic HRM practices in line with their well-being needs.

This study has a number of limitations. Firstly, the study is limited to public sector nurses and police officers and therefore further studies are required using other types of public sector employees - particularly professional employees. Another limitation is the use of self-report surveys causing common methods bias. However, Spector (1994) argues that the selfreporting method is a useful tool for gathering data about employees’ perceptions, as long the instrument reflects an extensive literature review and pattern-matching is used to support interpretations of the data. Moreover, there was a predominance of males in the police officer sample and a predominance of females in the nurse sample. However, the influence of gender was not tested in this research. One explanation for the difference in the significance of the relationship between LMX, well-being and affective commitment might be related to the greater number of male police officers and female nurses in the sample, possibly weighting the views they represent. Hence, further research is needed with relatively greater numbers of female police officers and male nurses to further test the model. The final limitation is the 
presence of some multicollinearity amongst the independent variables. The advantage of using the OLS approach is that it estimates parameters within an independent system, negating, to some extent, the problem of multicollinearity (Grapentine 2000). These limitations need to be addressed in future research.

\section{Conclusion}

This paper makes key contributions to HRM practitioners, particularly those in the public sector. The findings from this study suggest that public sector employees do not work in a uniform work context - particularly in relation to supervision practices - and four differences were identified between the two groups of public sector employees. These findings have implications for public sector managers. One of the goals of implementing NPM was to increase the efficiency and effectiveness of public sector organisations and the evidence suggests that increased efficiency has decreased per capita costs. However, as newspapers continue to report that wards within hospitals in OECD countries like Australia, NZ, USA and UK have been closed because of a lack of nurses and doctors (Buchan and Claman 2004), it seems likely that the way that the present HRM policy choices have been implemented is not achieving the organisational effectiveness goals promoted by governments as potentially possible with the implementation of NPM.

More research is required to further develop and empirically test employees’ perceptions of well-being so as to provide governments and public sector managers with more information about the link between government policy, implementation strategies, and employees’ levels of satisfaction with HRM policies and practices. 


\section{References}

Adcroft, A., and Willis, R. (2005). "The (un)intended outcome of public sector performance management”. International Journal of Public Sector Management, 18(5), 386-400.

Ackroyd, S., Kirkpatrick, I. and Walker, R (2007). "Public management reform in the UK and its consequences for professional organization: A comparative analysis”. Public Administration, 85(1), 9-26.

AHRI. (2003). “HR: Creating Business Solutions”. Melbourne: Australian Human Resources Institute and Committee for Economic Development of Australia.

Ahn, J. (2002). "Beyond single equation regression analysis: Path analysis and multi-stage regression analysis”. American Journal of Pharmaceutical Education, 66, 37-42.

Argyraides, D (2006). “The Rise, Fall, and Rebirth of Comparative Administration: The Rediscovery of Culture”. Public Administration Review 66 (2), 281-84.

Australian Bureau of Statistics. (2005). "Year Book Australia: Labour force participation in Australia”, Catalogue 6105.0. Canberra: Australian Bureau of Statistics.

Allen, N., and Meyer, J. (1990). "The measurement and antecedents of affective, continuance, and normative commitment to the organisation”. Journal of Occupation Psychology, 61(1), 1-18.

Beer, M., Spector, B., Lawrence, P., Mills, D., and Walton, R. (1985). Human Resource Management: A general manager's perspective. The Free Press. New York.

Bolton, S. (2005). "Making up managers: the case of NHS nurses work". Employment and Society, 19(1), 5-24.

Bolton, S.. (2003). "Multiple roles? Nurses as managers in the NHS”. International Journal of Public Sector Management, 16(2), 122-130.

Boyd, A. (1997). "Employee traps-corruption in the workplace”. Management Review, 86(8), 9.

Boyne, G. (2003). “What is public service improvement?” Public Administration, 81(2), 211227.

Boyne, G., Jenkins, G., and Poole, M, (1999). "Human Resource Management in the public and private sectors: An empirical comparison”. Public Administration, 77(2), 407-420.

Broadbent, J and Laughlin, R in McLaughlin, K; Osborne, S and Ferlie, E (2002) New Public Management Current trends and future Prospects. Routledge. UK, Ch 6, p95-128

Brunetto, Y. (2002). "The impact of growing managerialism amongst professionals in Australia: A comparative study of university academics and hospital nurses”. Research and Practice in Human Resource Management Journal, 10 (1), 1-25.

Brunetto, Y., and Farr-Wharton, R. (2004a). "A case study examining the impact of publicsector nurses' perception of workplace autonomy on their job satisfaction: lessons for management”. International Journal of Organisational Behaviour, 8(5) 521-539.

Brunetto, Y. and Farr-Wharton, R. (2004b). "Does the talk affect your decision to walk: A comparative pilot study examining the effect of communication practices on employee commitment post managerialism”. Management Decisions, 15 (7), 579-600.

Brunetto, Y., and Farr-Wharton R. (2005). "The impact of NPM on the job satisfaction of Australian public sector employees”. Asia Pacific Journal of Human Resources, 41 289104.

Brunetto, Y., and Farr-Wharton, R. (2006a). "The importance of effective organisational relationships for nurses: a social capital perspective”. International Journal of Human Resource Development and Management, 6(2), 232-247.

Brunetto, Y. and Farr-Wharton, R. (2006b). "A comparison of the administrative subculture of Australian public and private sector employees”. International Journal of Public Administration, 29 (8), 619-638. 
Brunetto, Y. and Farr-Wharton, R. (2007). “Comparing the impact of management practices on public sector nurses' and administrative employees' commitment to the organisation”. Asian Pacific Journal of Health Management, 2, 1.

Buerhaus, P., Staiger, D. and Auerbach, D. (2000). "Implications of an ageing registered nurse workforce”. Journal of American Medical Association, 283, 2948-2954

Buchan, J. and Calman, L. (2004). "The global shortage of registered nurses: An overview of issues and Actions". International Council of Nurses: Geneva

Buchanan, J., and Considine, G. (2002). "Stop telling us to cope: NSW nurses explain why they are leaving the profession”. A report for the NSW Nurses Association. University of Sydney Press. Sydney, Australian Centre for Industrial relations Research and Training.

Burke, R. J. and Greenglass, E. R. (2000). "Hospital restructuring and nursing staff well being: the role of coping”. International Journal of Stress Management, 7(1), 49-59.

Butterfield, R., Edwards, C. and Woodall, J. (2005). "The new public management and managerial roles: The case of the police sergeant”, British Journal of Management, 16: 219-341.

Contino, D. (2002). "How to slash costly turnover”. Nursing Management, 3(2), 10-30.

Cooper, C. L. and Cartwright, S. (1994). "Healthy mind; healthy organisation - a proactive approach to occupational stress”. Human Relations 47(4), 455-472.

Carroll, P and Steane, P in McLaughlin, K; Osborne, S and Ferlie, E (2002) New Public Management Current trends and future Prospects. Routledge. UK, Ch 12, p195-209

Daniels, K. and Guppy, A. (1997). "Stressors, locus of control, and social support as consequences of affective psychological well being”. Journal of Occupational Health Psychology, 2(2), 156-174.

Daniels, K., Brough, P., Guppy, A., Peters-Bean, K. M., Weatherstone, L. (1997). “A note on a modification to Warr's measures of effective well being at work". Journal of Workplace and Organizational Psychology, 70, 129-138.

Danna, K., and Griffin, R. W. (1999). "Health and well being in the Workplace: A Review and Synthesis of the Literature”. Journal of Management, 25(3), 357-384.

Degeling, P, Sage, D, Kennedy, J, Perkins, R and Zhang, K (1999) “A comparison of the impact of hospital reform on medical subcultures in some Australian and New Zealand Hospitals”. Australian Health Reviews 22(4), 172-184.

Denhardt, J and Denhardt, R (2007) The New Public Sector, Expanded Edition, ME Sharpe, NY

Diener, E. (1984). "Subjective well being”. Psychological Bulletin, 95(3), 542-575.

Diener, E., Suh, I. E. M., Lucas, R. E. and Smith, H. L. (1999). "Subjective well being: three decades of progress”. Psychological Bulletin, 125(2), 276-302.

Dunleavy, P., Margetts, H., Bastow, S and Tinkler, J (2006). "New Public Management Is Dead-Long Live the Digital-Era Governance". Journal of Public Administration Research and Theory, 16 (3), 467-94.

Emmert, M. and Taher,W., (1992). "Public Sector Professionals: The Effects of Public Sector Jobs, Job Satisfaction and Work Involvement". American Review of Public Administration, (1) 37-48.

Epitropaki, O. and Martin, R. (1999). "The impact of relational demography on the quality of leader-member exchanges and employees' work attitudes and well-being”. Journal of Occupational and Psychology, 72, 237-240.

Fay, D. and Luhrmann, H. (2004). "Current Themes in Organizational Change”. European Journal of Work and Organizational Psychology, 13(2): 113-119.

Ferlie, E., Pettigrew, A., Ashburner, L., and Fitzgerald, L. (1996). The New Public Management in Action. Oxford, Oxford University Press. 
Fisher, R, Maltz, E and Jaworski, B (1997). "Enhancing communication between marketing and engineering: The moderating role of relative functional identification”. Journal of Marketing, 61(3) 54-70.

Ghauri, P., and Gronhaug, K. (2002). Research Methods in Business Studies. Harlow, Prentice Hall.

Gerstner, C. and Day, D. (1997). "Meta-analytic review of leader-member exchange theory: Correlates and construct issues”. Journal of Applied Psychology, 82, 827-844.

Gollan, P. (2005). "High Involvement management and Human resource Sustainability: The challenges and opportunities”. Asia Pacific Journal of Human Resources 43(1) 18-33.

Goris, J., Vaught, B. and Pettit, J. (2000). "Effects of Communication direction on job performance and satisfaction: A moderated regression analysis". Journal of Business Communication, 37(4) 348-68.

Gould-Williams, J. (2004). “The Effects of 'High Commitment' HRM practices on Employee Attitude: The views of Public Sector Workers”. Public Administration 82 (1) 63-81.

Graen, G. and Uhl-Bien, M. (1995). "Relationship-based approach to leadership: Development of leader-member exchange (LMX) theory of theory over 25 years: Applying a multi-level multi-domain perspective”. Leadership Quarterly, 6(2), 219-247.

Gray, J., and Laidlaw, H (2002). "Part-time employment and communication satisfaction in an Australian retail organisation”. Employee Relations, 24 (1/2), 211-218.

Grapentine, T. (2000). "Path analysis vs. structural equation modeling”. Marketing Research, 12(3), 13-20.

Guest, D., and Conway, N. (1997). Employee Motivation and the Psychological Contract. Institute of Personnel and Development 21, 1-60.

Haskins, W. (1996). "Freedom of speech: Construct for creating a culture which empowers organisations members”. Journal of Business Communication, 33 (1), 85-89.

Harris, P. (1999). "Changing Patterns of Governance. Developments in Australian public hospitals and Universities”. Policy Studies 20(4), 255-272.

Hegney, D., Plank, A., Buikstra, E., Parker, V., and Eley, R. (2005). "Nurses. Worth listening to”. Queensland Nurses Union, Centre for Rural and Remote Area Health, University of Southern Queensland, Toowoomba.

Hood, C (1995) “Emerging Issues in Public Management”. Public Administration 73 (1)165183.

Janssen, O., and van Yperen., N. (2004). "Employee's goal orientation, the quality of leadermember exchange, and the outcomes of job performance and satisfaction”. Academy of Management Journal, 47, 368-84.

Judge, T and Watanabe, S (1993) "Another look at the job satisfaction-life satisfaction relationship”. Journal of Applied Psychology, 78 (6) 939-948

Kirkpatrick, I., and Ackroyd, S. (2003). "Transforming the Professional Archetype? The new managerialism in UK social services”. Public Management Review, 5(4), 511-531.

Lapierre, L. and Allen, T. D. (2006). "Work-supportive family, family-supportive supervision, use of organisational benefits, and problem-focused coping: implications for work-family conflict and employee well being”. Journal of Occupational Health Psychology, 11(2)169-181.

McLaughlin, K;, Osborne, S and Ferlie, E (2002) New Public Management Current trends and future Prospects. Routledge. UK

Meyer, J., and Allen, N. (1997). Commitment in the workplace: Theory, research and application. Thousand Oaks, Sage Publications.

Meyer, J., and Herscovitch, L. (2001). "Commitment in the workplace - Toward a general model”. Human Resource Management Review, 11(3), 299-326.

Mikkelsonsen, A and Lovrich, N (2000) "Modeling the effects of organizational setting and 
individual coping style on employees subjective health, job satisfaction and commitment”. Public Administration Quarterly, Fall, 371-397

Morland, A., Steel, M., Alexander, M., Stephen., K., and Duffin., L. (1997). Changes at Work: The Australian Workplace Industrial Relations Survey. Melbourne, Addison Wesley Longman.

Mueller, B and Lee, J (2002). "Leader-member exchange and organizational communication satisfaction in multiple contexts”. Journal of Business Communication, 39 (2) 220-244

Newman, K., Maylor, U., and Chansarkar, B. (2002). "The nurse satisfaction. Service quality and nurse retention chain: Implications for management of recruitment and retention”. Journal of Management in Medicine 16(4/5), 271-292.

OECD. (2003). Maintaining a prosperous society: Ageing research report. Geneva: Organisation for Economic Co-operation and Development.

Orchard, L (1998). "Managerialism, Economic Rationalism and Public Sector Reform in Australia: Connections, Divergences, Alternatives”. Australian Journal of Public Administration 57 (1) March 19-32.

Ostroff, C and Bowen, D. (2000). Moving HR to a higher level. HR practices and organizational effectiveness. In K. Klein and S. Kozlowski (eds) Multilevel theory, research, and methods in organizational Psychology (pp.211-266). San Francisco, CA: Jossey-Bass.

Ostroff, C., Kinicki, A and Clark, M (2002). "Substantive and operational issues of response bias across levels of analysis: An example of climate-satisfaction relationships". Journal of Applied Psychology, 87, 355-368

Robinson, S., T. Murrells and M. Clinton. 2006. 'Highly qualified and highly ambiguous: Implications for workplace retention of realizing the career expectations of graduate nurses in England.' Human Resource Management Journal 16, 3, 287-312.

Parasuraman, S., Greenhaus, J. H., and Granrose, C. S. (1992). "Role stressors, social support, and well being among two career couples”. Journal of Organisational Behaviour 13(4): 339-356.

Pitt, M., Leyl, F., Foreman, S. K., and Bromfield, D. (1995). “Organisational commitment and service delivery: Evidence from an industrial setting in the UK”. International Journal of Human Resource Management, 6(1), 369-389.

Politt, C., and Baichaert, G. (1995). Quality Improvements in European Public Services, Cases and Commentary. London, Sage.

Power, M. (1997). The Audit Society: rituals of Verification. Oxford, Oxford University Press

Price, R. H. and Hooijberg, R. (1992). "Organisational exit-pressures and role stress: impact on mental health”. Journal of Organisational Behaviour, 13(7), 641-651.

Productivity Commission. (2005). Australia's Health Workforce. Canberra: Productivity Commission, Commonwealth of Australia.

Shah, C., and Burke, G. (2003). "Skills shortages: concepts, measurement and implications: Working paper no. 52”. Centre for the Economics of Education and Training, Monash University: Melbourne.

Shortell, S., Zimmerman, J., Rousseau, D., Draper, E., Knaus, W., and Duffy, J. (1994). The Performance of Intensive Care Units: Does Good Management Make a Difference?, Medical Care, 32(5), 508-525.

Simons, T. and Roberson, Q. (2003). "Why managers should care about fairness: The effects of aggregate justice perceptions on organizational outcomes". Journal of Applied Psychology, 88, 432-443.

Smith, K., Kaminstein, D. S., and Makadok, R. J. (1995). “The health of the corporate body: Illness and organizational dynamics”. Journal of Applied Behavioural Science, 31, 328351. 
Spector, P. E. (1994). "Using self-reported questionnaires in OB research: A comment on the use of a controversial method”. Journal of Organizational Behavior 15(5) 385-392.

Spreitzer, G. (1995). "Psychological empowerment in the workplace: Dimensions, Measurement and Validation”. Academy of Management Journal 38(5), 1442-1465.

Spreitzer, G. (1996). "Social Structural Characteristics of Psychological Empowerment". Academy of Management Journal 39(2), 483-504.

Stanton, P., Bartram, T. and Harbridge, R. (2004) 'People management practices in the public health sector: Developments from Victoria, Australia', Journal of European Industrial Training, 28(2/3/4/), 310-328.

Thompson, C. A. and Prottas, D. J. (2006). "Relationships among organisational family support, job autonomy, perceived control, and employee well being”. Journal of Occupational Health Psychology 11(1), 100-118.

Thomsen, S., Arnetz, B., Nolan, P., Soares, G. and Dallender, G. (1999). Individual and organisational well being in psychiatric nursing: a cross-cultural study. Journal of Advanced Nursing 30(3), 749-757.

Van der Doef, M., and Maes, S. (1999). The Job Demand-Control (-Support) Model and psychological well-being: a review of 20 years of empirical research. Work and Stress, 13 (2), 87-114.

Wanless, D. (2000). Securing Our Future Health: Taking a Long-Term View. London, HMSO

Warr, P. (1987). Work, unemployment, and mental health. Oxford, Claredon Press.

Warr, P. (1990). The measurement of well being and other aspects of mental health. Journal of Occupational Psychology 63, 193-210.

Wayne, S., Shore, L., and Linden, R (1997). Perceived organisational support and leader exchange: A social exchange perspective. Academy of Management 40(1), 82-111

Whittington, R., McNulty, T., and Whipp, R. (1994). Market driven change in professional services: problems and processes. Journal of Management Studies 31(6), 829-845.

Wright, T. A. and Bonett, D. G. (1992). The effect of turnover on work satisfaction and mental health: support for a situational perspective. Journal of Organisational Behaviour 13(6): 603-615. 
Table 1: Demographics: Nurse, Police Officers Age * Gender

\begin{tabular}{|l|c|c|c|}
\hline Details & Under 30 & $\mathbf{3 1 - 4 5}$ & $\mathbf{4 5 +}$ \\
\hline Nurse Males & 1 & 13 & 6 \\
\hline Nurse Females & 35 & 59 & 50 \\
\hline Police Males & 1 & 84 & 45 \\
\hline Police Females & 0 & 38 & 10 \\
\hline
\end{tabular}

Table 2: The well-being construct

\begin{tabular}{|l|l|l|}
\hline $\begin{array}{l}\text { Variables } \\
\text { "Employees } \\
\text { 'perception of } \\
\text { satisfaction with the } \\
\ldots \text {..” }\end{array}$ & Questions & $\begin{array}{l}\text { Means } \\
\text { (Standard } \\
\text { Deviation) }\end{array}$ \\
\hline $\begin{array}{l}\text { Eudaimonic part of } \\
\text { well-being }\end{array}$ & $\begin{array}{l}\text { Overall, I think being a nurse/police officer fulfils an } \\
\text { important purpose in my work life. }\end{array}$ & $4.5(1.09)$ \\
\hline & $\begin{array}{l}\text { Overall, I get enough time in nursing/policing to reflect } \\
\text { on what I do at work }\end{array}$ & $3.9(1.4)$ \\
\hline $\begin{array}{l}\text { Hedonic part of well-- } \\
\text { being }\end{array}$ & $\begin{array}{l}\text { Overall I think I am reasonably satisfied with my work } \\
\text { life. }\end{array}$ & $4.22(1.15)$ \\
\hline & $\begin{array}{l}\text { Overall, most days I feel a sense of accomplishment in } \\
\text { what I do in nursing/policing }\end{array}$ & $4.43(1.15)$ \\
\hline
\end{tabular}

Scale: 1=Strongly Disagree, 2=Disagree, 3=Slightly Disagree, 4=Slightly Agree, 5=Agree and 6=Strongly Agree

Table 3: Correlations and Reliability (Alpha) Scores

\begin{tabular}{|l|l|l|l|l|l|}
\hline & & 1 & 2 & 3 & 4 \\
\hline 1 & Age & 1 & & & \\
\hline 2 & Supervision & .077 & 1 & & \\
\hline 3 & Well-being & -.105 & $.65^{* *}$ & 1 & $(.88)$ \\
\hline 4 & Affective Commit & -.059 & $.6 * *$ & $.635^{* *}$ & $1(.85)$ \\
\hline
\end{tabular}


Table 4: Results from Main Effects Regression Analysis of supervision on employees' levels of well-being (Statistically significant beta scores)

\begin{tabular}{|l|l|l|l|}
\hline Variables & $\begin{array}{l}\text { Well-being } \\
\text { F=230.288** }\end{array}$ & $\begin{array}{l}\text { Nurses Well- } \\
\text { being } \\
\text { F=70.82** }\end{array}$ & $\begin{array}{l}\text { Police Well-being } \\
\text { F=19.399** }\end{array}$ \\
\hline Model 1 & & & $.315^{* *}$ \\
\hline $\begin{array}{l}\text { Satisfaction } \\
\text { supervision (LMX) }\end{array}$ & with & $.55^{* * *}$ & $\mathbf{9 . 9 \%}$ \\
\hline $\mathbf{R}^{2}$ & $\mathbf{4 2 . 5 \%}$ & $\mathbf{3 0 . 4 \%}$ & \\
\hline
\end{tabular}

Statistically significant beta scores, ${ }^{* *} \mathrm{p}<.01,{ }^{*} \mathrm{p}<.05$, Two-tailed tests.

Table 5: Results from Main Effects Regression Analysis of supervision on employees' levels of well-being (Statistically significant beta scores)

\begin{tabular}{|l|c|l|c|}
\hline Variables & $\begin{array}{l}\text { Total Affective } \\
\text { Commitment } \\
\text { F=199.957** }\end{array}$ & $\begin{array}{l}\text { Nurses Affective } \\
\text { Commitment } \\
\text { F=72.7** }\end{array}$ & $\begin{array}{l}\text { Police Affective } \\
\text { Commitment } \\
\text { F=11.428** }\end{array}$ \\
\hline Model 1 & & $-.55^{* *}$ & $-.247^{* *}$ \\
\hline $\begin{array}{l}\text { Satisfaction } \\
\text { supervision (LMX) }\end{array}$ & $.6^{* *}$ & $\mathbf{3 1 \%}$ & $\mathbf{6 . 1 \%}$ \\
\hline $\mathbf{R}^{2}$ & $\mathbf{3 6 . 8 \%}$ & & \\
\hline
\end{tabular}

Statistically significant beta scores, ${ }^{* *} \mathrm{p}<.01,{ }^{*} \mathrm{p}<.05$, Two-tailed tests.

Table 6: Results from Main Effects Regression Analysis of well-being on employees' levels of affective commitment (Statistically significant beta scores)

\begin{tabular}{|l|l|l|l|}
\hline Variables & $\begin{array}{l}\text { Affective } \\
\text { Commitment } \\
\text { overall }\end{array}$ & $\begin{array}{l}\text { Affective } \\
\text { Commitment } \\
\text { of nurses }\end{array}$ & $\begin{array}{l}\text { Affective } \\
\text { Commitment of } \\
\text { police officers }\end{array}$ \\
\hline & $\mathbf{F}=199.157^{* *}$ & $\mathbf{F}=\mathbf{7 2 . 7 0 8 * *}$ & $\mathbf{F}=11.428^{* *}$ \\
\hline Well being & $.6 * *$ & $.557^{* *}$ & $.247^{* *}$ \\
\hline $\mathbf{R}^{2}$ & $\mathbf{3 7 \%}$ & $\mathbf{3 1 \%}$ & $\mathbf{6 . 1 \%}$ \\
\hline
\end{tabular}

Statistically significant beta scores, ${ }^{* *} \mathrm{p}<.01,{ }^{*} \mathrm{p}<.05$, Two-tailed tests.

Table 7: Results from Main Effects Regression Analysis of LMX and well-being on employees' levels of affective commitment (Statistically significant beta scores)

\begin{tabular}{|l|l|l|l|}
\hline Variables & $\begin{array}{l}\text { Affective } \\
\text { Commitment } \\
\text { overall }\end{array}$ & $\begin{array}{l}\text { Affective } \\
\text { Commitment of } \\
\text { police }\end{array}$ & $\begin{array}{l}\text { Affective } \\
\text { Commitment of } \\
\text { nurses }\end{array}$ \\
\hline & $\mathrm{F}=149.921^{* *}$ & $\mathrm{~F}=72.684 * *$ & $\mathrm{~F}=13.575^{* *}$ \\
\hline
\end{tabular}




\begin{tabular}{|l|l|l|l|}
\hline $\begin{array}{l}\text { Satisfaction } \\
\text { supervision (LMX) }\end{array}$ & with & $.338^{* *}$ & $.254^{* *}$ \\
\hline Well being & $.415^{* *}$ & $.506^{* *}$ & $.285^{* *}$ \\
\hline $\mathbf{R}^{2}$ & $\mathbf{4 6 . 9 \%}$ & $\mathbf{4 7 . 4 \%}$ & $\mathbf{1 3 . 4 \%}$ \\
\hline
\end{tabular}

Statistically significant beta scores, ${ }^{* *} \mathrm{p}<.01,{ }^{*} \mathrm{p}<.05$, Two-tailed tests.

Table 8: Results from Independent Samples Test

\begin{tabular}{|c|c|c|c|c|c|}
\hline $\begin{array}{l}\text { Nurses=164 } \\
\text { Police=178 }\end{array}$ & $\begin{array}{l}\text { Mean } \\
\text { (Standard } \\
\text { Deviation) } \\
=\text { Strongly } \\
\text { Disagree } \\
\text { through to } \\
6=S \text {. } \\
\text { Agree }\end{array}$ & $\begin{array}{l}\text { Levene's } \\
\text { For equ. } \\
\text { Variance } \\
* \quad \text { Equal } \\
\text { variances } \\
\text { assumed }\end{array}$ & & t-test & $\begin{array}{l}\text { Equality } \\
\text { Means }\end{array}$ \\
\hline & $\begin{array}{l}\text { Nurses }=1 \\
\text { Police }=2\end{array}$ & $\mathbf{F}$ & $\mathbf{T}$ & Df & $\begin{array}{ll}\text { Sig } & (2 \\
\text { tailed })\end{array}$ \\
\hline Age & $\begin{array}{l}2.12(.74) \\
2.33(.54)\end{array}$ & $11.63^{* *}$ & -2.968 & 324 & .05 \\
\hline Gender & $\begin{array}{l}1.87(.32) \\
1.26(.44)\end{array}$ & $53.63 * *$ & 14.462 & 325 & .001 \\
\hline $\begin{array}{l}\text { Satisfaction with } \\
\text { Supervision (LMX) }\end{array}$ & $\begin{array}{l}4.5(1.8) \\
2.6(.99)\end{array}$ & 2.011 & 16.827 & 340 & .001 \\
\hline Well being & $\begin{array}{l}4.27(1.0) \\
2.95(.99)\end{array}$ & .887 & 12.066 & 340 & .001 \\
\hline Affective Commitment & $\begin{array}{l}3.44(.97) \\
4.89(1.1)\end{array}$ & .95 & 119.12 & 340 & .001 \\
\hline
\end{tabular}


Figure 1: Proposed model: Supervisor practices, employees’ perceptions of wellbeing and affective commitment
HR Policy
Choices
HR
Outcomes

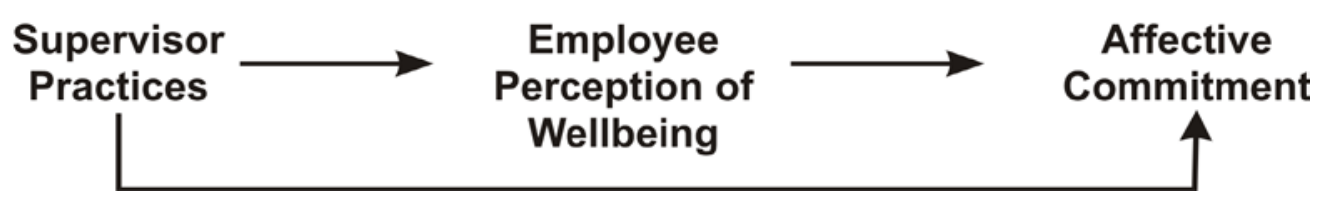

Figure 2: Confirmation of goodness of fit for model describing the relationship between supervisor practices, employees' perceptions of well-being and affective commitment

HR Policy

Choices
HR

\section{Outcomes}

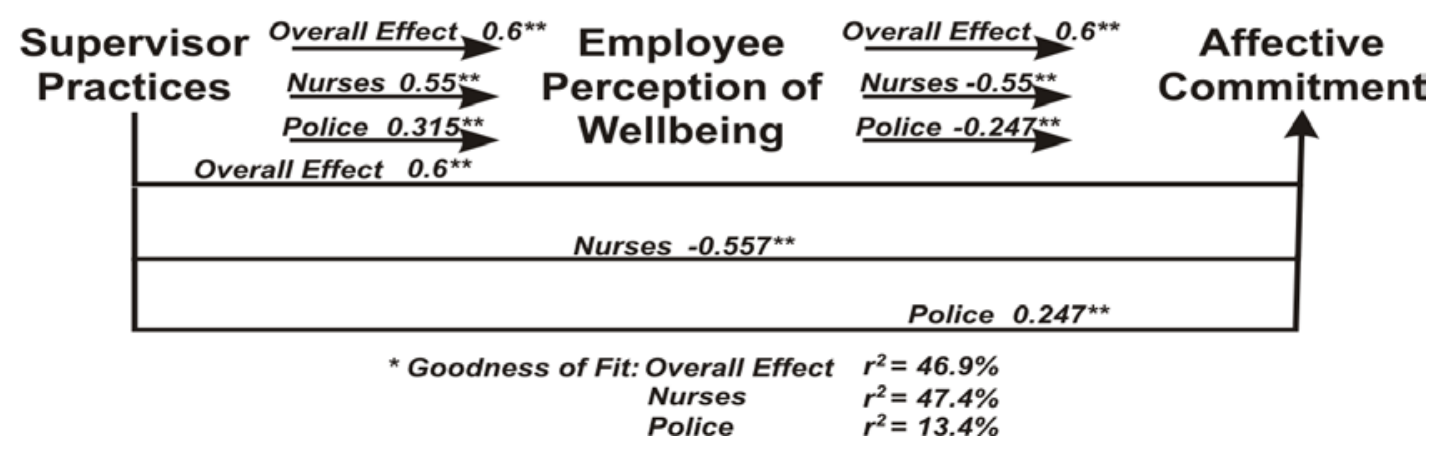

